\title{
Environmental Legal Culture as a Factor in Ensuring Sustainable Development of Society
}

\author{
By Liudmyla Kurylo ${ }^{1}$, Inna Kurylo ${ }^{2}$, Ievgenii Shulga ${ }^{3}$, Iryna Horodetska ${ }^{4}$
}

\begin{abstract}
The purpose of the article is to clarify the role and importance of environmental legal culture in ensuring the sustainable development of society. Methodological basis of the research includes general theoretical principles of scientific knowledge (comprehensiveness, validity, complexity), which allowed to provide various aspects in the study of ecological legal culture. It is based on a complex combination of research approaches, the leading among which is integrative, as well as general scientific methods (formal-logical, structural and functional). Scientific novelty is to identify the essence and importance of environmental legal culture as one of the main factor for ensuring the sustainable development of society. Based on the analysis of scientific-theoretical approaches of the understanding of environmental culture, legal culture, environmental legal culture, as well as the current legislation and sources devoted to diagnostics of the effectiveness of the implementation of national environmental policy, it is substantiated that environmental legal culture is a complex integral category that includes a complex of interconnected cognitive, value and activity components, characterized by a certain level of environmental and legal knowledge and active activity in their practical reality ted; is a factor in the effectiveness of legal regulation of public relations in the field of environmental protection and an effective instrument of environmental policy in the country, and therefore a factor in ensuring the sustainable development of society.
\end{abstract}

Keywords: environmental culture, legal culture, environmental legal culture, environmental policy, sustainable development.

\section{Introduction}

The negative phenomena and processes that characterize the current crisis situation of Ukrainian society, in particular, economic and political instability, and, as a consequence, social tensions and confrontational tendencies in governmental structures, do not contribute to achieving the goals of sustainable development. In addition, the deepening of the ecological crisis caused by, among other things, the increasing anthropogenic load on the environment is a serious problem, which makes it impossible to ensure the effective socio-economic development of the country. At the same time, it should be emphasized that the above-mentioned destructive processes have close causeand-effect relations with the phenomena of devaluation of moral and ethical values, legal nihilism, extremely low level of ecological consciousness, and consequently, deficiency of

\footnotetext{
| ${ }^{1}$ Doctor of Science of Economics, professor, professor of the Department of Marketing and Business Management of National University of Kyiv-Mohyla Academy.

${ }^{2}$ Doctor of Science of Law, associate professor, professor of the Department of International Law and Comparative Law of the National University of Life and Environmental Sciences of Ukraine.

${ }^{3}$ Doctor of Science of Law, associate professor of the Department of International Law and Comparative Law of the National University of Life and Environmental Sciences of Ukraine.

${ }^{4}$ Doctor of Science of Law, associate professor, professor of the Department of Political Science, Law and Philosophy of Nizhyn Mykola Gogol State University.
} 
environmental legal culture, which necessitates the creation of conditions for its proper formation and development.

\section{Discussion}

The purpose of the article is to clarify the role and importance of environmental legal culture in ensuring the sustainable development of society.

Various aspects of the study of environmental legal culture have been given attention by such scientists as H. Audzei, F. Sabatini, V.I.Andreytsev, I.L. Borodin, G.I. Balyuk, T.V. Bachinsky, K.G. Volinka, V.V. Demicheva, N.I.Zolotaryova, V.S. Kovalsky, A.M. Kolodiy, V.V. Kostitsky, M.V. Krasnova, S.L. Lysenkov, L.O.Makarenko, S.I. Maksimov, O.M. Melnyk, T.V. Morozovskaya, A.P. Ovchinnikova, N.M. Onishchenko, E.V. Poznyak, P.M. Rabinovich, O.D. Tikhomirov, T.O. Chepulchenko, B.O. Chuprinsky, Yu.S. Shemshuchenko, V.V. Shishko, O.M. Shumilo and others.

Natural-organic existence is combined with social, life in economic, political, legal, religious, scientific and other social spheres, and spiritual life, which is the embodiment of culture. Throughout his life man lives in the world of culture, through which he formed and mastered the principles of construction of the surrounding world and its place in it (Onishchenko, 2010; Usenko, 2006). Prominent Austrian thinker of the twentieth century, biologist, founder of etiology Konrad Lorenz, whose works not only determine the further paths of science, but also have a significant impact on selfknowledge of man, argued that in our time, for the first time in world history, the hope to achieve the natural -scientific understanding of the most complex of all living systems - human society. "Man as a species," he says, "is now at the turn of times ... The thinking acquired by our culture through its natural sciences enables it to escape the destruction that has befallen all the high cultures of the past" (Lorenz, 2008).

Besides theoretical considerations on the shifting terminology concerning culture (ranging from cultural property to tangible or intangible cultural heritage, to cultural goods or products), the role of culture in society has constantly been renegotiated through its contamination with other branches of knowledge: from the development of cultural economics, to the interest in creative industries to, ultimately, the recent debate on the role of culture in sustainable development ( Sabatini, 2019).

The existence in the scientific sources of a great variety of variants of the definition of the concept of "culture" is due to the complexity of revealing the essence of the multidimensional nature of the studied social phenomenon. There are a number of areas of study of culture in the humanities: historical-genetic, anthropological, socio-cultural (activity-behavioral), axiological, technological, civilization, communicative, psychological, cross-cultural, etc. (Rabinovich, Bachinsky, 2015). Environmental culture, as an integral part of the general culture, is the object of research by scientists through the prism of philosophy, ethics, aesthetics, sociology, ecology, law and law. For this reason, formulating a universal definition of it is a difficult task because, along with its strengths, there will always be controversial and even weak points.

This is evidenced by the latest scientific developments, which pay much attention to the many definitions of environmental culture existing in scientific research. In particular, the environmental culture is regarded as: the set of material and spiritual values created 
by man; "Second nature," that is, all created and transformed by a human; specific mode of human activity; universal means of social life of people; sphere of human creativity; well-established, universally recognized elements of the human-created world (norms, skills, rituals, stereotypes and patterns of behavior, etc.); the boundaries of a person in the world; the degree of humanization of society and a human; the system of values and the process of their realization; system of traditions; process and result of formation of environmental consciousness; a complex system of principles, relationships, values, and the totality of all the transformative activities by which these values are formed; purposeful human activities aimed at organizing and transforming the natural world in accordance with one's own needs and intentions; instrument of state environmental policy, etc. (Dubovy, V.I., Dubovy, O.V., 2016; Radey, 2008; Morozovska, 2013; Poznyak, 2012; Kurnyak, 2015). At the same time, the analysis of definitions of the term "environmental culture" in the scientific literature indicates that quite often the definitions defined by scientists are constructed on the basis of artificial synthesis and selective integration of certain features proposed by other researchers dealing with relevant topics.

Explaining the main socio-philosophical approaches to understanding and exploring the concepts of "environmental consciousness" and " environmental culture", A.S. Radey concludes that environmental culture $"<\ldots>$, based on the integrity of the system "society-nature", includes a dialectical synthesis of environmental relations, environmental activities and environmental consciousness." According to the author, the main link, an integrating factor, is environmental activity (Radey, 2008).

Considering environmental culture as an integral category that absorbs many components, L.M. Kurnyak distinguishes several interconnected and interpenetrating components in its structure: cognitive, emotional-aesthetic, value and activity. At the same time, the scientist emphasizes that environmental consciousness is the basis of environmental culture (Kurnyak, 2015).

In general, in the vast majority, scholars identify the three main components of environmental culture, in particular: the appropriate level of environmental knowledge (intellectual component); appropriate level of environmental awareness (value component); adequate stock of practical and environmental management skills (activity component). It is difficult to disagree that the combination and coherence of these three components determines the formation of an environmental culture of personality, on the level of which depends largely on the resolution of the global environmental crisis, ensuring the survival and progress of mankind (Dubovy, V.I., Dubovy, O.V., 2016; Kurnyak, 2015).

It should be emphasized that at least some positive changes should be expected to achieve a balanced correlation of socio-economic and environmental development until Ukrainian society understands and recognizes the crucial importance of environmental culture for social life. It is worth agreeing completely with the opinion of Professor G.I. Balyuk, who points out that Ukraine today needs a balanced development in which production and consumption will be economical and caring for natural resources, will enable natural ecosystems to recover, to be safe for humans, to support the life of future generations. Balanced development includes many components, but according to the scientist, it is not possible without changing the environmental outlook of all citizens, 
without environmental education, consciousness, culture of society (Balyuk, 2012).

It is global environmental education in general and environmental legal education in particular that contribute to the formation of a new, planetary thinking, a sense of belonging and responsibility for the fate of the planet. Environmental education was put forward by UNESCO and the United Nations Environment Program as one of the main means of harmonizing the interaction between man and nature. The Stockholm Conference on the Human Environment (1972) adopted a Recommendation on the creation of an international program on environmental education. By the beginning of 1975, the ball program was developed by UNESCO jointly with the UN Commission on the Environment (UNEP) ( Audzei, 2019).

According to part 1 of the art. 7 of the Law of Ukraine "On Environmental Protection", enhancement of the environmental culture of society and professional training of specialists are provided by the general compulsory comprehensive education and education in the field of environmental protection, including in preschool institutions, in the system of general secondary, professional and higher education, advanced training and retraining (On the protection of the environment, 1991).

There is no doubt that environmental education and education for sustainable development are important factors in shaping the modern outlook of the average citizen of Ukraine and the main mechanisms for implementing sustainable consumption and production in Ukraine. Unfortunately, we currently have a number of problems that need to be addressed as soon as possible, in particular: neither the concept nor the strategy for education for sustainable development has yet to be finalized in Ukraine; the lack of clear decisions on integrating environmental education into the curricula of secondary schools and higher education institutions; unacceptable state of affairs in the training of environmental specialists.

We have carried out a detailed analysis of a rather large-scale document on the diagnostics of the effectiveness of the implementation of national environmental policy, in particular, "Evaluation of the implementation of the State Environmental Policy of Ukraine for the period up to 2020 and the National Environmental Action Plan for 2011-2015". It made it possible to detect the effectiveness of the implementation of the strategic Objective 1 "Raising the level of social environmental awareness".

In particular, it should be noted that in the context of these program documents, there is a positive dynamics of the fulfillment of such strategic tasks as: creation of an environmental training system and upgrading of qualifications of civil servants, whose competence is related to environmental protection; creation of a network of regional environmental education centers based on educational institutions, non-governmental environmental organizations, etc.; systematic information on the activities of executive bodies in the field of environmental protection through official websites and mass media; establishing and implementing a mechanism for ensuring public access to environmental information and participation in decision-making in accordance with the provisions of the Convention on Access to Information, public participation in decision-making and access to justice in environmental matters (the Aarhus Convention); facilitating the publication and dissemination of a report by public environmental organizations on public assessment of national environmental policy; providing state support for the creation and development of settlements using energy and resource-saving technologies 
for housing construction, and integrated implementation of such technologies (Ministry of Energy and Environment Protection of Ukraine, 2014).

At the same time, a considerable number of strategic tasks are being performed at an unsatisfactory level.

Thus, strategic tasks whose progress in implementation is unsatisfactory (effectiveness less than 30\%) include: creation of a national environmental information system; facilitating the development of information centers, territorial bodies of a specially authorized body of executive power on environmental protection and the Aarhus Information Center established under a specially authorized body of executive power on environmental protection; creation of a network of national automated information and analytical system for access to environmental information, including, in particular, the national system of inventories of natural resources, registers of emissions and transfer of pollutants, and by 2020 - environmental information management system in accordance with EU standards; development and implementation of the Environmental Education Strategy by 2015 with the aim of sustainable development of Ukrainian society and economy of Ukraine; development of organizational mechanism of local, regional and national level for active involvement of the public in the process of environmental education for the purpose of sustainable development, environmental education and upbringing; assisting local communities in implementing sustainable farming and environmentally friendly technologies; creation in each area of information-experimental and demonstration-training centers of support of measures for introduction and dissemination of models of sustainable economy and environmentally friendly technologies by 2020; integration of environmental culture, environmental education and education issues into national targeted, regional and local development programs (Ministry of Energy and Environment Protection of Ukraine, 2014). In addition, the effectiveness of the implementation of a number of measures envisaged under Strategic Objective 1 is $0 \%$, they have not been implemented at all. Thus, it should be noted that the state's progress in raising the level of social environmental consciousness and, consequently, of environmental culture, is not satisfactory.

The task of forming new approaches to improving the administrative and legal framework of European integration processes is dictated not only by the objectives of the very environmental reform in Ukraine, but also by the processes of integration of the Ukrainian society into a single European space, bringing the standards of state and political activity to the standards common in the European community. Practical activity in implementing the institutional and administrative potential of European integration is the direct introduction of European standards in all spheres of public life and the involvement of the broader public of Ukrainian society in this process (Gulac, 2019).

EU Technical Assistance Project "Additional support from the Ministry of Ecology and Natural Resources of Ukraine in implementing Sector Budget Support" together with the Strategic Planning Unit prepared "Diagnostics of the State Environmental Policy of Ukraine for the Period up to 2020 and the National Environmental Action Plan 20112015 years identifies the major and immediate causes of Ukraine's environmental problems, as well as the goals and sequence of actions (political, socio-economic, financial, administrative, public, etc.) that would help achieve long-term goals of the state environmental quality and eliminate the environmental problems and their root causes. 
In general, the analysis of the sources devoted to the diagnosis of the effectiveness of the implementation of national environmental policy indicates that the main reasons for the poor fulfillment of a number of strategic goals and objectives are: problems of public administration; corruption; insufficient funding; lack of incentives for eco-innovation; unsatisfactory organizational, technical and informational component of management; shortcomings of legal regulation (Horodetska, 2016). One of the main factors that determine the effectiveness of legal regulation of social relations by many scientists is reasonably related to the level of justice and legal culture of the subjects of law (the opinions of a scientists like V.V. Galunko, V.S. Kovalsky, A.M.Kolodiy, M.V. Kravchuk, S.L.Lysenkov, A.M. Melnyk, O.D. Tikhomirov, I.M. Chopin and others).

Despite the fact that the theory of legal culture is multifaceted by legal science, the interest in this field is not diminishing. Legal culture has repeatedly been the subject of reflection on legal scholars who have formulated and explored different approaches to its understanding. Among the scientific works of recent years, it is necessary to distinguish a monographic study of P.M.Rabinovich and T.V. Bachinsky, in which considerable attention has been paid to: the characterization of the main views on the concept of "legal culture" and the approaches that have been formed in the process of studying this phenomenon by a number of scholars; revealing the interconnection of the legal worldview, justice and legal culture, their distinctive features; the current state and peculiarities of the formation of the foundations of the legal worldview, justice and legal culture (Rabinovich \& Bachinsky, 2015), as well as the scientific work of the team of authors "Action Law: An Integrative Aspect", in which, among other things, the deformation manifestations of consciousness (legal nihilism, legal infantilism, legal negativism and legal fetishism are analyzed) and ways of overcoming them are offered, and legal culture is considered as a factor of ensuring the effect of law (Onishchenko, 2010).

As it is rightly stated by I.L. Borodin, "the legal culture of the individual is an integral part of the general culture of society and in its dialectical development closely interacts with other types of culture - political, moral, ethical, environmental, etc., which also serve the function of social-legal orientation of people in a particular society" (Borodin, 2016). At the same time, recent scientific studies emphasize that contemporary culture is a set of different cultural microcosms that need to be synthesized as a whole (Rabinovich \& Bachinsky, 2015).

\section{Conclusions}

The analysis of scientific sources points to the existence of different approaches to understanding the environmental legal culture. In particular, the environmental legal culture is considered as a component of environmental culture, which is a socially significant and regulated by the law the way of creative activity in the knowledge and transformation of nature, its protection, the rational use of natural resources, environmental improvement for the benefit of present and future generations (Poznyak, 2012; Kravchenko, 1988). Instead, other scholars, while criticizing the previous approach, regard the environmental legal culture as a specific form (an integral part) of the legal culture. In particular, it is emphasized that: this type of legal culture is often 
confused with environmental culture, which should be understood as "the culture of all kinds of human activity, one way or another related to the cognition, development and transformation of nature (Sheyafetdinova, 2003); the environmental legal culture, which is formed on the basis of only the rules of environmental law and is a narrower concept than environmental culture as such (Burkin, 2014). At the same time, paying due attention to the contribution of scientists to the study of this issue, in principle, we share the approach according to which environmental legal culture is the result of the synthesis of environmental culture and legal culture.

Summarizing the above, we can conclude that environmental legal culture is a complex integral category, which includes a complex of interrelated components - cognitive, value, activity, characterized by a certain level of environmental and legal knowledge and active activity in their practical implementation. Environmental legal culture is a factor in the effectiveness of legal regulation of public relations in the field of environmental protection and an effective instrument of environmental policy in the country, and therefore a factor in ensuring the sustainable development of society.

\section{References}

Audzei, H. (2019). The Role of Environmental Law Education for Sustainable Development. European Journal of Sustainable Development, 8(3), 79. https://doi.org/10.14207/ejsd.2019.v8n3p79.

Balyuk, G.I. (2012). Legal support of ecological component of sustainable development: problems of legislative regulation, creation of ecological capital of the world and improvement of ecological education in Ukraine. The Bulletin of Taras Shevchenko National University of Kyiv. Legal Studies, 92, 9-13.

Borodin, I.L. (2016). The legal culture of the individual in the rule of law. Yurydychnyi visnyk, 3 (40), 191193.

Burkin, D.O. (2014). Legal education in the mechanism of formation of environmental legal culture. PhD. thesis. Krasnodar, 239.

Diagnosis of the State Environmental Policy Strategy of Ukraine for the Period up to 2020 and the National Environmental Action Plan for 2011 - 2015. Official site of the Ministry of Ecology and Natural Resources of Ukraine. Available at: http://old.menr.gov.ua/public/discussion/3742-diahnostykstratehii-derzhavnoi-ekolohichnoi-polityky-ukrainy-na-period-do-2020-roku.

Dubovy, V.I., \& Dubovy, O.V. (2016). Ecological culture. Kherson, 256.

Gulac, O., Goshovska, V., Goshovskyi, V., \& Dubchak, L. (2019). New Approaches to Providing of Environmental Management in Ukraine on the Way to Euro Integration. European Journal of Sustainable Development, 8(2), 45. https://doi.org/10.14207/ejsd.2019.v8n2p45

Horodetska, I.A. (2016). To the question of implementation of the state policy in the area of protection, use and reproduction of the animal world. Economics, management, law: problems of establishing and transformation: Collection of scientific articles. Dubai, UAE, 295-298.

insurance. Investment Management and Financial Innovations,

insurance. Investment Management and Financial Innovations,

insurance. Investment Management and Financial Innovations,

Kravchenko, S.N. (1988). Socio-psychological aspects of legal environmental protection. Lviv, 154.

Kurnyak, L.M. (2015). Ecological culture: concepts and formation. Zbirnyk naukovykh prats Khmelnytskoho instytutu sotsialnykh tekhnolohii Universytetu «Ukraina», 10, 48-51.

Lorenz, K. (2008). The so-called evil. Moscow: Kulturnaia revoliutsyia, 606.

Ministry of energy and environment protection of Ukraine (2014) Evaluation of the implementation of the State Environmental Policy Strategy of Ukraine for the period up to 2020 and the National Environmental Action Plan for 2011-2015. Available at:// Official site of the. URL: https://menr.gov.ua/news/29270.html .

Morozovska, T.V. (2013). Ecological Culture of the Lawyer. Naukovyi visnyk NUBIP: Law, 182, 158-1669. 
of the insurance market of Ukraine amid the global trends in of the insurance market of Ukraine amid the global trends in of the insurance market of Ukraine amid the global trends in

On the protection of the environment: Law of Ukraine of 25.06.1991 № 1264-XII. Available at:http://zakon5.rada.gov.ua/laws/show/1264-12.

Onishchenko, N.M. (Eds.). (2010). Law action: integrative aspect: monograph. Kyiv, 360.

Poznyak, E. (2012). Theoretical and Legal Foundations of Ecological Culture in Ukraine. The Bulletin of Taras Shevchenko National University of Kyiv. Legal Studies, 92, 24-28.

Rabinovich, P.M., Bachinsky, T.V. (2015). Formation of the basics of legal outlook, legal consciousness and legal culture of school youth (theoretical and sociological and legal research) Lviv, 224.

Radey, A.S. (2008). Environmental consciousness and culture: theoretical and methodological aspect. Visnyk NTUU «KPI». Filosofiia. Psykholohiia. Pedahohika, 3 (24). Available at: http://ela.kpi.ua/bitstream/123456789/8812/1/15.pdf.

Sabatini, F. (2019). Culture as Fourth Pillar of Sustainable Development: Perspectives for Integration, Paradigms of Action. European Journal of Sustainable Development, 8(3), 31. https://doi.org/10.14207/ejsd.2019.v8n3p31

Sheyafetdinova, N.A. (2003). Ecological and legal culture and ecologized legal awareness. Citizens' Rights, Law Enforcement and Law Enforcement Activities in Russia and Ukraine: State and Development Prospects: Proceedings of international practice. conf. Belgorod, 198-202.

Usenko, I.B. (2006). Legal custom as a source of Ukrainian law of the IX - XIX centuries. Kyiv, 280. 